\title{
ANALISIS SERAPAN KOSAKATA BAHASA ARAB TERHADAP BAHASA BIMA
}

Sri Wahyuningsih M.Pd.I dan Nurul Zuhriyah M.Pd.I

clie.wahyu1@gmail.com \& zuhriyahhnurul@gmail.com

(Dosen Pendidikan Bahasa Arab IAI Muhammadiyah Bima)

\section{الملتخص}

هذا البحث بالموضيوع: تحليل امتصاص المفردات اللغة العربية في اللغة البيماوية. بخلفية البحث يعني امتصاص المفردات تكون من إحدى العوامل فعال في تأثير تطوير اللغة. يوقع الامتصياص في المفردات

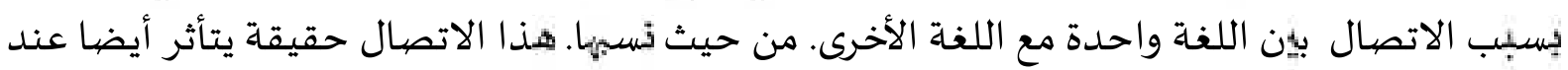
لغتهم (بيما). والمثال بسيطة هو اشتعار اللكلمات. التطور بين اللغات يتفرق بين بِعضيهم بِعض. مض المفردات من اللغة البيماوية دائما يتطور، وليس فقط من جهاة امتصاص اللغة بِعناصر القرابة، مثل اللغة

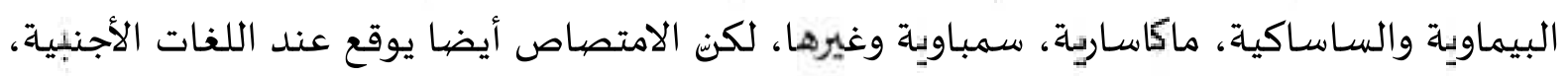

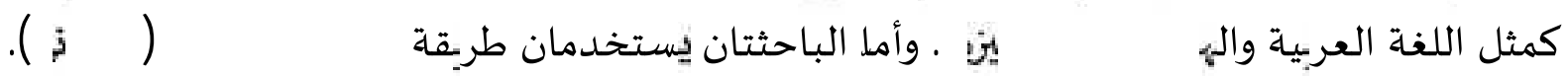

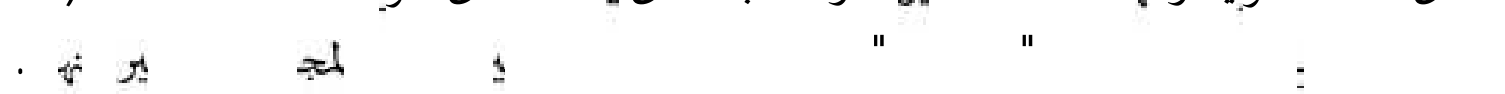
وأما النتائج من هذا البحث هي التصور عن حياة المجتمع بيما، الواقعي مازال كثير مثهم الذين لا يِعلمون

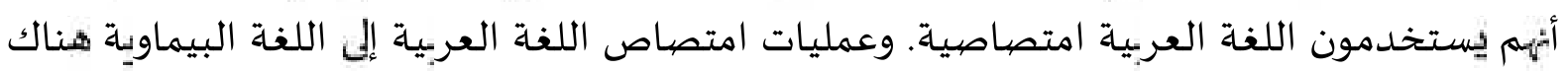
أسباب: (). د خول الاسلام في بيما، ץ). تغيير سياسة سلطان بيما، ऍ). بيما كمنطقة من طر.قة التجارة

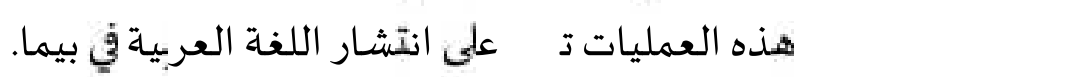
المفردات من اللغة بيما المتي امتصاص من اللغة العربية متنوعة، من حيث ترتيب الموروتية

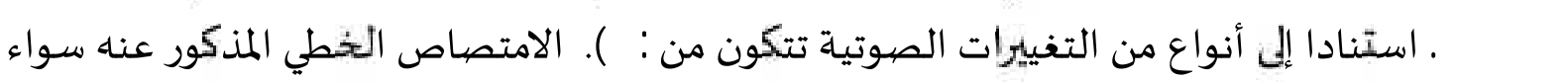

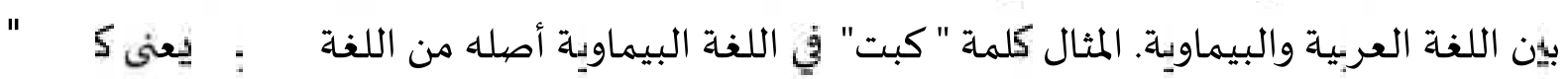

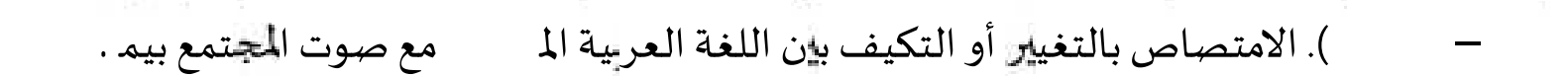

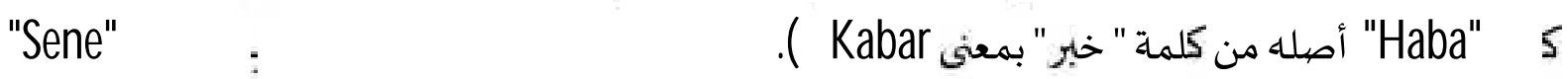

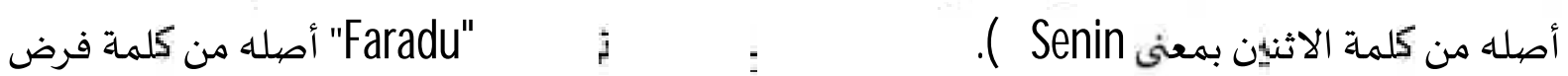

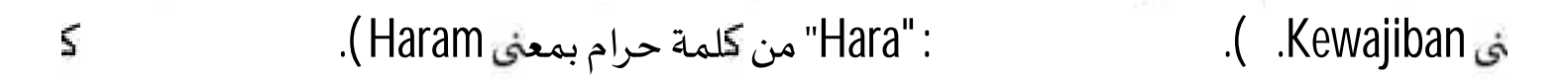
"Mafaka"

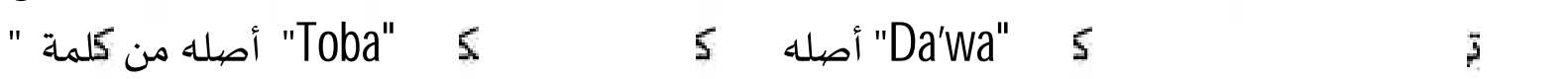
طاب - يطوب " . اما تغيير المعنى كمثلفي الكلمة "Habe" وأمل كلمة حبيبب. كلمات المفتاح : امتصاص، المفردات، اللغة العربية، اللغة البيماوية 
Judul penelitian ini yaitu "Analisis Serapan Kosakata Bahasa Arab terhadap Bahasa Bima". Dengan latar belakang penelitian yaitu; Kata serapan menjadi salah satu faktor yang sangat aktif dalam menentukan perkembangan bahasa. Penyerapan terjadi akibat adanya kontak antara satu bahasa dengan bahasa lainnya. Baik yang sekerabat maupun yang tidak sekerabat. Kontak dengan bahasa- bahasa lain menimbulkan saling adanya pengaruh dalam bahasa mereka dan pengaruh yang paling sederhana yaitu berupa peminjaman kosakata karena perkembangan antara bahasa yang saling mempengaruhi pastilah berbeda. Kosakata bahasa Bima terus berkembang bukan hanya menyerap kosakata dari bahasa- bahasa yang masih ada unsur kekeluargaan dengan bahasa Bima seperti bahasa Sasak, Makassar, Sumbawa, dan lainnya, tetapi juga bahasa- bahasa asing seperti bahasa Arab dan Belanda dan Inggris.

Metode penelitian yang digunakan adalah penelitian kualitatif yaitu dengan jenis penelitian lapangan (Field Research) yang juga dianggap sebagai pendekatan luas dalam penelitian kualitatif. Penelitian ini menggunakan teori pendekatan sosiolinguistik oleh Haver C. Currie yang merupakan teori yang mengkaji antara hubungan bahasa dengn masyarakan yang saling mempengaruhi satu sama lain.

Hasil penelitian ini menggambarkan proses penyerapan bahasa Arab terhadap bahasa Bima ini terjadi karena adanya; pertama Masuknya Agama Islam di Bima, kedua Kebijaan Kesultanan Bima (perubahan sistem kerajaan menjadi kesultanan), ketiga; Bima Sebagai Daerah Jalur Lintas Perdagangan Nusantara. Proses penyerapan ini memberikan dampak tersendiri bagi tersebarnya bahasa Arab di Bima, memunculkan beberapa ungkapan bahasa Bima yang diserap dari bahasa Arab. Bentuk kosakata bahasa Bima hasil serapan dari bahasa Arab beragam, baik dari tatanan fonologi maupun semantiknya. Berdasarkan Tipe- Tipe Perubahan Fonetik terdiri dari: pertama; Penyerapan linier; contoh kata "kabata" dalam bahasa Bima diserap dari kata bahasa Arab /kabata yang berarti menghina, kedua; Penyerapan dengan perubahan atau penyesuaian; contoh kata "haba" dari kata

/khabar yang berarti kabar", ketiga; Penyerapan dengan penghilangan; contoh kata "sene" dari kata / isnain yang berarti senin, keempat; Penyerapan dengan penambahan fonem; contoh "faradu" dari kata /Fardhu yang beratri wajib, kelima; Penanggalan parsial; contoh "hara" dari kata

/haram yang berarti hukum haram (dosa bila dikerjakan), keenam; Perpaduan/merger; contoh kata "mafaka" dari kata /muwaafaqah yang berarti mufakat, ketujuh; Pembelahan/ split contoh kata "jeka" dari kata /zakah yang berarti zakat. Berdasarkan macam- macam Perubahan bunyi ada asimilasi seperti pada kata " menjadi kata da'wa" dan disimilasi seperti kata "Toba dari kata ". Sedangkan perubahan makna atau semantik terjadi pada contoh kata serapan "Habe dalam bahasa Bima berarti panggilan untuk orang Arab, sedangkan dari bahasa Arab kata habiib/حبي "berarti kekasih".

\section{Kata Kunci: Serapan, Kosakata, Bahasa Arab, Bahasa Bima}




\section{A. PENDAhULUAN}

Pada umumnya masyarakat Bima secara tidak sadar dalam kehidupan sehari-hari telah banyak menggunakan ungkapan atau kosakata bahasa Arab yang terserap ke dalam bahasa Bima. Kurangnya kesadaran masyarakat Bima terhadap penggunaan bahasa Arab di Bima disebabkan kurangnya pengetahuan tentang bentuk penyerapan bahasa yang terjadi, yang mana sebagian kata bahasa Arab yang terserap ke dalam bahasa Bima tidak sepenuhnya diserap secara utuh atau secara keseluruhan sama dengan penyebutan dan makna seperti bahasa Arab sebenarnya. Hal ini disebakan oleh perbedaan karakter vokal dan budaya masyarakat antara dua bahasa. Seperti contoh kata "kahawa" (Kopi) dalam bahasa Bima yang diserap dari bahasa Arab yaitu kata قهوة qohwah (Kopi), Beberapa kata yang diserap dari bahasa Arab juga ada yang mengalami peminjaman makna seperti dari nama "Bilal bin Rabah/ ". dalam bahasa Bima kata "Bilal " digunakan untuk penyebutan seorang muazin, dan pengurus masjid disebut "Robo" dari nama akhir Bilal yaitu "Rabah ". Selain itu ada juga yang mengalami pergeseran makna seperti kata "habiib/ dبيب dalam bahasa Arab bermakna kekasih dalam bahasa Bima digunakan sebagai sapaan untuk orang yang berasal dari Arab yaitu "habe".

Diantara penyebab terjadinya serapan bahasa Arab terhadap bahasa Bima adalah proses ekspansi Islam ke seluruh penjuru dunia termasuk ke bumi Nusantara. Para pedagang muslim dari Arab, Persia dan anak benua India yang mendatangi kepulauan Nusantara tidak hanya berdagang, tetapi dalam batas tertentu juga menyebarkan Islam kepada penduduk setempat. ${ }^{1}$ Renaffaer berpendapat bahwa di Bima pengaruh Arab dan Melayu sangat kuat, karena inskripsi Bima ditulis dalam bahasa Arab dan bahasa Melayu, bukan dengan huruf dan bahasa Bima atau Bugis. Demikian dengan posisi Bima menjadi salah satu pusat perdagangan pada rute lintas Malaka dan Maluku yang merupakan daerah yang disinggahi sepanjang rute pelayaran- perdagangan. ${ }^{2}$ Bima sebagai salah satu bandar lintas pelayaran- perdagangan Malaka dan Maluku menjadi penting artinya sebagai tempat singgah aktivitas perdagangan. ${ }^{3}$ Faktor lain yaitu, adanya akulturasi budaya yang didahului dengan proses perpindahan penutur suatu bahasa ke lingkungan penutur bahasa yang lain,

\footnotetext{
${ }^{1}$ Azyumardi Azra, Jaringan Ulama Timur Tengah Dan Kepulauan Nusantara Abad Xvii Dan Xviii: Melacak Akar- Akar Pembaruan Pemikiran Islam di Indonesia, (Bandung; Mizan, 1995, Cet.3), 17.

2 Tawalinuddin Haris, dkk Tradi “ Kerajaan sional di Indonesia- Bima” (Jakarta: CV.Putra Sejati Raya, 1997), 35

${ }^{3}$ Ibid., 49.
} 
sehingga terjadilah perubahan dialek-dialek baru, penciptaan kata-kata baru, bahkan sering terjadi perubahan susunan sintaksisnya ${ }^{4}$. Demikian dengan Bima, yang bernotabene sebagai daerah teluk tempat transit pedagang-pedagang Makassar, Bugis, Arab dan bahkan Cina yang menuju laut Malaka, Banda, Ternate dan mengalami akulturasi budaya yaitu salah satunya adanya penyerapan bahasa. ${ }^{5}$

\section{B. METODE PENELITIAN DAN TEKNIK ANALISIS DATA}

Metode penelitian ini adalah penelitian kualitatif yaitu Penelitian lapangan (Field Research) yaitu mempelajari secara intensif tentang latar belakang keadaan sekarang, dan interaksi suatu sosial, individu, kelompok, lembaga, dan masyarakat ${ }^{6}$. Bogdan dan Biklen berpendapat bahwa salah satu karakteristik penelitian kualitatif adalah data deskriptif ${ }^{7}$.

Peneliti menggunakan metode penelitian deskriptif kualitatif karena penelitian ini menguraikan proses penyerapan kata Bahasa Arab terhadap bahasa Bima, dan menguraikan bentuk kata bahasa Bima yang diserap dari bahasa Arab, dengan bantuan bermacam macam material yang terdapat di dalam kamus kamus, buku-buku, majalah, dokumen, catatan dan kisah-kisah sejarah. ${ }^{8}$

Metode Pengumpulan data dalam penelitian ini menggunakan metode wawancara, dokumentasi, dan observasi. Sumber data yang digunakan yaitu data primer; Sumber data yang berasal dari hasil wawancara dengan para tokoh masyarakat, tokoh adat, tokoh agama, dan masyarakat Bima umumnya. Data sekunder; Berasal dari semua pustaka yang dapat dijadikan sumber objek kajian sperti; kamus praktis bahasa Bima, kamus Mahmud Yunus, Kamus Al Munawwir, Kamus besar bahasa Arab, sedangkan dari buku-buku antara lain; Buku BO' Sangaji kai, buku Aksara Bima, buku Patu Mbojo. Adapun analisis data yang dipakai dalam penelitian ini dapat dilakukan secara deskriptif yaitu; data collecting, data editing, data reducting, data display. data verifikasi, data konklusi.

\section{PEMBAHASAN}

Hubungan antara bahasa dan masyarakat dapat dikaji dengan menggunakan teori

\footnotetext{
${ }^{4}$ Erwin dkk, "Penggunaan Bahasa Mbojo Di Lingkungan Masyarakat Bima Di Bima: Sebuah Kajian Variasi Bahasa" e-Journal Program Pascasarjana Universitas Pendidikan Ganesha Program Studi Pendidikan Bahasa dan Sastra Indonesia (Volume 2 Tahun 2013), 2-3.

5 Siti Maryam "Bandar Bima”, (DEPDIKBUD: Jakarta, 1992), 82..

${ }^{6}$ Husaini Usman dkk, Metodologi Penelitian Sosial, (Jakarta: PT. Bumi Aksara, 2006), 5.

${ }^{7}$ Emzir, Metodologi Penelitian Kualitatif Analisis Data, (Jakarta: PT RajaGrafindo Persada, 2010),23

${ }^{8}$ Mardalis, Metode Penelitian: Suatu Pendekatan Proposal, (Jakarta: Bumi aksara, 2008), 28.
} 
sosiolinguistik. Bahasa dalam kajian sosiolinguistik dipandang sebagai sistem sosial dan sistem komunikasi yang merupakan bagian dari masyarakat berkaitan dengan berbagai faktor, baik faktor kebahasaan itu sendiri maupun faktor non kebahasaan, misalnya faktor sosial budaya yang meliputi status sosial, umur, tingkat pendidikan dan jenis kelamin. ${ }^{9}$

Chaer dan Agustina mengatakan sosiolinguistik yaitu pengkajian bahasa (linguistik) sebagaimana bahasa itu berada dan berfungsi dalam masyarakat (sosiologis). Dengan demikian, sosiolinguistik adalah bidang ilmu antardisiplin yang mempelajari bahasa dalam kaitannya dengan penggunaan bahasa itu dalam masyarakat. ${ }^{10}$

\section{Hakikat Penyerapan Kosakata}

Penyerapan dari satu bahasa ke bahasa lain dapat terjadi secara leksikal. Pada proses penyerapan unsur bahasa secara leksikal akan terbawa juga proses penyerapan bunyi. Penyerapan leksikal dapat dibedakan menjadi tiga, yaitu penyerapan dialek, penyerapan mesra dan penyerapan kultural. Dan di samping penyerapan leksikal juga terdapat penyerapan struktural, yang termasuk dalam penyerapan ini yaitu yang menyangkut unsur fonem, morfem dan kalimat. ${ }^{11}$

Masuknya bahasa Arab ke dalam bahasa Bima menyebabkan persinggungan kedua aturan bahasa yang berbeda, karena pada hakikatnya sifat bahasa adalah dinamis terus berkembang. Diantara perubahan pada kata serapan yaitu:

\section{a) Perubahan Fonologis pada Kata Serapan}

Berdasarkan buku Linguistik Bandingan Historis ada dua macam perubahan fonologis pada kata-kata serapan, yaitu: ${ }^{12}$

\section{1) Berdasarkan Tipe-Tipe Perubahan Fonetis:}

a) Penyerapan Linier

b) Penyerapan dengan perubahan atau penyesuaian

c) Penyerapan dengan penghilangan

d) Penyerapan dengan penambahan

e) Penanggalan parsial,

f) Perpaduan (merger)

\footnotetext{
${ }^{9}$ Suwito, Pengantar Awal Sosiolinguistik Teori dan Problema. (Surakarta: UNS Press. 1983), 2

${ }^{10}$ Chaer, Abdul dan Leonie Agustina. Sosiolinguistik: Perkenalan Awal.(Jakarta: PT Rineka Cipta, 1995), 4

${ }^{11}$ Samsuri Analisa Bahasa, (Jakarta: Erlangga, 1994), cet.ke 9, 52-53

${ }^{12}$ Gorys Keraf, Linguistik Bandingan Historis (Jakarta: Gramedia, 1984), 80-94
} 
g) Pembelahan (split).

\section{2) Berdasaran Macam- Macam Perubahan Bunyi}

a) Asimilasi. ${ }^{13}$

b) Disimilasi yaitu bunyi yang berubah menjadi kurang mirip dengan yang lain di sekitarnya. $^{14}$

c) Perubahan berdasarkan tempat dapat diperoleh beberapa macam perubahan bunyi, yaitu: Metatesis, Aferesis, Sinkop, Apokop, Epentesis/ mesogok, Paragok. ${ }^{15}$

\section{b) Tataran Semantik}

Semantik adalah bidang studi yang mempelajari makna atau arti dalam bahasa. ${ }^{16}$ Semantik merupakan cabang ilmu linguistik yang mempunyai hubungan erat dengan ilmu-ilmu sosial seperti, sosiologi, antropologi, bahkan juga dengan filsafat dan psikologi. ${ }^{17}$ Oleh karena itu, arti kata pada suatu bahasa akan memiliki arti yang berbeda dengan bahasa lain, bahkan kata-kata hasil serapan akan mengalami perubahan dengan bahasa protonya. Perubahan semantik atau perubahan makna dapat ditinjau dari beberapa segi yaitu; Pertama; Generalisasi/ perluasan, kedua; Spesialisasi pengkhususan/ penyempitan, ketiga; Ameliorasi/ peninggian, keempat; Peyorasi/ penurunan, kelima; Sintesia/ pertukaran, keenam; Asosiasi persamaan; perubahan makna yang terjadi karena persamaan sifat. ${ }^{18}$

\section{Hakikat Bahasa Arab dan Bahasa Bima}

Bahasa Arab adalah susunan kata atau kalimat yang diucapkan oleh masyarakat Arab untuk mengungkapkan maksud dan kehendak mereka, dan telah sampai pada kita dengan cara perpindahan atau perkembangan, dengan bahasa arab tersebut maka kita bisa menghafal dan menjaga al-Qur'an dan hadits-hadits Nabi, hadits-hadits Nabi tersebut diriwayatkan dengan cara yang tsiqoh (kuat) dari peninggalan bangsa Arab dengan aturanaturanya sampai pada kita hingga pada zaman sekarang ini. Sedangkan bahasa Bima atau Nggahi Mbojo adalah sebuah bahasa Austonesia yang dipertuturkan oleh suku Bima di

\footnotetext{
${ }^{13}$ Abdul Syukur Ibrahim dan Machrus Syamsudin, Prinsip dan Metode Linguistik Historis, (Surabaya: Usaha Nasional, 1979), 16.

${ }^{14}$ Abdul Syukur Ibrahim dan Machrus Syamsudin, Prinsip dan Metode Linguistik Historis, (Surabaya: Usaha Nasional, 1979), 16.

${ }^{15}$ Gorys Keraf, Linguistik Bandingan ............, 90-92.

${ }^{16}$ Abdul Chaer, Pengantar Semantik ............., 2.

${ }^{17}$ Ibid., 4.

${ }^{18}$ Lamuddin Finoza, Komposisi bahasa Indonesia, (Jakarta: Diksi Insan Mulia, Cet. Ke 9, 2003), 82.
} 
pulau Sumbawa bagian timur, NTB yang terdiri dari Bima, Dompu dan sebagian wilayah di Manggarai NTT. ${ }^{19}$ Bahasa Bima atau Nggahi Mbojo dipergunakan oleh masyarakat umum di Bima dan berfungsi sebagai bahasa ibu. Aksara bahasa Bima banyak persamaan dengan aksara Makasar kuno dan apabila kedua aksara tersebut dibandingkan dengan aksara sansekerta, maka dapat dipastikan asal usul keduanya berasal dari aksara sansekerta (Zollinger). Menurut tingkatannya bahasa Bima dibagi dalam 3 tingkat, yaitu tingkat halus/bahasa istana, tingkat menengah yaitu bahasa sehari-hari dan tingkat rendah/kasar. ${ }^{20}$

Perbedaan bunyi antara kedua bahasa tersebut disebabkan oleh adanya bunyi bahasa di dalam bahasa Arab yang tidak dimiliki oleh bahasa Bima, demikian pula antara lambang bunyi antara kedua bahasa tersebut tidak sama. Bahasa Arab menggunakan lambang bunyi yang disebut huruf hijaiyah yang ditulis dari arah kanan ke kiri, sedangan bahasa Bima menggunakan lambang bunyi yang disebut abjad dengan penulisan latin dan arah penulisannya diawali dari kiri ke kanan.

\section{HASIL DAN TEMUAN PENELITIAN}

\section{Proses Penyerapan Kosakata Bahasa Arab terhadap Bahasa Bima}

\section{a. Ekspansi Agama Islam di Bima}

Menurut Sejarahwan M. Hilir Ismail, tahun 1540 M merupakan tonggak awal kedatangan Islam di tanah Bima. Proses islamisasi itu berlangsung dalam tiga tahap yaitu periode kedatangan Islam tahun 1540 - 1621, periode pertumbuhan Islam tahun 1621-1640 M, dan periode kejayaan Islam pada tahun 1640 - 1950 M. Pada tahap awal Islam menjadi agama resmi kerajaan, ajaran Islam sudah masuk di wilayah-wilayah pesisir Bima. ${ }^{21}$

Pada tahap kedua, Islam masuk di Bima melalui Ternate. Pada masa Sultan Khairun, sultan Ternate ketiga (1536-1570), telah dibentuk aliansi Aceh-DemakTernate. Dan juga telah dibentuk lembaga kerjasama Al Maru Lokatul Molukiyah yang diperluas istilahnya menjadi Khalifah Imperium Nusantara. Pada masa sultan Baabullah (tahun 1570-1583), usaha penyiaran Islam semakin ditingkatkan dan pada masa inilah, para Mubaliq dan pedagang Ternate meningkatkan kegiatan dakwah di Bima. Hal itu terus berlanjut sesuai keterangan BO Istana, bahwa para

\footnotetext{
${ }^{19}$ Fachrir Rahman, Nika Mbojo Antara Islam Dan Tradisi, (Mataram: Alamtara Institut, 2011), 15.

${ }^{20}$ I Wayan Tama, dkk Fonologi Bahasa Bima, (Jakarta: Depdikbud, 1996), 1.

${ }^{21}$ M.Hilir Ismail, Kebangkitan Islam di Dana Mbojo (BIMA), (Bogor: CV Binasti, 2008), 1.
} 
Mubaliq dari Sulawesi Selatan yang dikirim oleh Sultan Alauddin Gowa tiba di Sape pada tanggal 11 Jumadil Awal $1028 \mathrm{H}$ bertepatan dengan tanggal 16 April 1618, tiga belas tahun setelah Raja Gowa dan Tallo memeluk Agama Islam, bahkan lima belas tahun setelah Raja Luwu memeluk Agama Islam. ${ }^{22}$

Dari sini dapat diketahui bahwa masuknya agama Islam di tanah Bima tentu memberikan sumbangsi besar bagi masyarakat Bima dalam mengenal kata- kata bahasa Arab, terutama yang berkaitan dengan istilah- istilah Arab dalam ilmu keislaman. Hal ini terlihat juga pada penggunaan kata- kata bahasa Arab oleh pendatang Arab yang ikut membantu mengembangkan Islam di Bima. Mereka bertempat tinggal di kampung yang berdekatan dengan Kampo Melayu yaitu “Kampo Bente" (Kampung Benteng). ${ }^{23}$

\section{Kebijaan Perubahan Sistem Kerajaan Menjadi Kesultanan}

Pemerintah kesultanan yang berdasarkan ajaran Islam dan adat yang Islami berlangsung selama lebih kurang 310 tahun. Para Sultan dan ulama berhasil mengukir sejarah yang gemilang, pada masa itu Islam mengalami kejayaan. Bima tersohor sebagai pusat penyiaran Islam di wilayah Nusantara bagian Timur. Rakyatnya terkenal sebagai penganut agama Islam yang taat. ${ }^{24}$ Para Sultan Bima melakukan berbagai kebijakan yang memacu perkembangan Islam. Dilaksanakannya peringatan dan perayaan "Molu" (maulud), ndiha Aru Raja To `i (perayaan menyambut Hari Raya Idul Fitri) dan ndiha Aru Raja Na`e (perayaan menyambut Hari Raya Idul Adha), mampu meningkatkan kualitas iman dan taqwa umat. ${ }^{25}$ Mulai saat itu jikir marhaban dan barjanji dipelajari dan dilantunkan dalam upacara. Daur hidup seperti khitanan, khatam al-Qur`an dan pernikahan. ${ }^{26}$

Perubahan yang dilakukan oleh Sultan Abdul Khair Sirajudin bersama Datuk Raja Lelo dan kawan-kawan, bukan hanya terbatas pada upacara peringatan hari-hari besar agama, tetapi juga pada bidang-bidang lain. Guna meningkatkan peran ulama di bidang pemerintah, maka dibentuk lembaga yang bernama Sara Hukum. Mulai saat itu

\footnotetext{
${ }^{22}$ Henri Chambert-Loir dan Siti Maryam R. Salahuddin, Bo' Sangaji Kai: Catatan Kerajaan Bima, (Yogyakarta: Yayasan Obor Indonesia, 2013), 67.

${ }^{23}$ M.Hilir Ismail, Kebangkitan Islam .............., 16.

${ }^{24}$ Ibid., 33.

${ }^{25}$ Ibid., 97.

${ }^{26}$ Ibid., 98.
} 
pemerinttah kesultanan memiliki tiga lembaga yaitu Sara Tua, Sara-Sara dan Sara Hukum. Lembaga ini akan menangani pembangunan di bidang agama dan hukum. Lembaga sara dan hukum dipimpin oleh seorang Qadhi atau Imam. Di bantu oleh Khatib (Khatib Tua, Khatib Karota, Khatib Lawili dan Khathib To`i), Lebe Na`e, Cepe Lebe, Bilal dan Robo. ${ }^{27}$

Pendidikan yang berpusat di masjid dan langgar menjadi tanggung jawab lembaga Sara dan Hukum. Peran Lebe Na`e dan Cepe Lebe dalam bidang pendidikan di tingkat kejenelian dan desa sangatlah besar. Pendidikan agama khususnya bagi anak-anak usia sekolah (6-12 tahun) diserahkan kepada Guru Ngaji yang mengajar al-Qur’an dan membimbing murid-muridnya dalam urusan ibadah seperti sholat dan puasa.

Sebagai negara Islam maka huruf Arab Melayu (Arab Gundul) ditetapkan sebagai aksara resmi Kesultanan. Menggantikan aksara Mbojo lama yang diadopsi dari aksara Makassar, yang banyak persamaannya dengan aksara Sansekerta. Seluruh masyarakat dianjurkan untuk belajar membaca dan menulis aksara huruf Arab Melayu. Surat-surat resmi dan dokumen kesultanan ditulis dengan huruf Arab Melayu, termasuk naskah BO Istana. Dampak positif dari penggunaan aksara melayu adalah masyarakat termasuk anak- anak akan mudah membaca kitab suci al-Qur`an. Bagi orang- orang dewasa yang ingin memperdalam ilmu agama dirasakan sangat membantu. Mereka sudah mempelajari kitab-kitab Islam yang pada umumnya ditulis dengan aksara Arab Melayu.

Dalam waktu yang bersamaan, ditetapkan bahwa kalender Hijriah dan angka Arab, menjadi kalender dan angka yang diberlakukan secara resmi oleh pemerintah Kesultanan. Seluruh anggota masyarakat harus mampu menghafal nama-nama bulan Hijriah mulai dari bulan Muharam sampai dengan Zulhijah. Angka (bilangan) Arab dipelajari dan dipergunakan dalam kehidupan sehari-hari. Nama-nama hari juga harus dengan nama Arab. Pada masa kesultanan, masyarakat tidak mengenal nama hari Minggu, mereka hanya mengenal istilah "Sajama 'a" (se-Jum'at) atau "sepekan" dalam bahasa Indonesia. $^{28}$

\footnotetext{
${ }^{27}$ Ibid., 97.

${ }^{28}$ Ibid., 99-100.
} 


\section{Bima Sebagai Daerah Lintas Perdagangan}

Keadaan alam Bima dengan hasil alamnya yang cukup beragam dan menjadi bahan ekspor yang sangat laris pada zamannya. Inilah yang merupakan salah satu sebab Bima bisa tampil sebagai daerah maritim tersohor sejak abad 15 sampai pertengahan abad 20 M. Pada abad ke-16 M, Bima sudah menjadi salah satu pusat perdagangan yang ramai di wilayah bagian timur Nusantara. Menurut Tome Pires yang berkunjung ke Bima pada tahun $1513 \mathrm{M}$, pada masa itu pelabuhan Bima ramai dikunjungi oleh para pedagang Nusantara dan para pedagang Bima berlayar menjual barang dagangannya ke Ternate, Banda dan Malaka serta singgah di setiap pelabuhan di Nusantara. Pada saat inilah kemungkinan para pedagang Demak datang ke Bima selain berdagang juga untuk menyiarkan agama Islam. Bima dianggap sebagai salah satu kota perdagangan yang terpenting. Oleh karena itu, kompeni Hindia Belanda selalu berusaha keras membuat perjanjian-perjanjian mengenai hak-hak monopoli dan penyerahan-penyerahan yang menguntungkan, khususnya kayu sapar dan samar. Perdagangan tidak dilakukan oleh orang-orang Bima sendiri, tetapi sebagian besar dipegang oleh orang Makassar, Bugis, Arab dan beberapa orang Cina. ${ }^{29}$ Adanya kontak perdagangan yang menghasilkan sosial/budaya memberikan dampak tersendiri bagi tersebarnya bahasa Arab di Bima, memunculkan beberapa ungkapan bahasa Bima yang diserap dari bahasa Arab, Bugis dan bahasa lainnya, yang telah dipergunakan oleh masyarakat Bima dalam kehidupan sehari hari, baik itu secara sadar maupun tidak.

\section{Bentuk Penyerapan Kosakata Bahasa Arab terhadap Bahasa Bima}

Penyerapan kosakata bahasa Arab ke dalam bahasa Bima akan terlihat bahwa kosakata bahasa Arab memperkaya khasanah kosakata bahasa Bima, penyerapan bahasa Arab ada yang tidak semua diterima secara utuh, tetapi ada juga yang diserap melalui penyesuain huruf dan lafal atau ucapannya. Hal ini terjadi karena antara bahasa Arab dan bahasa Bima mempunyai sistem bunyi dan lambang bunyi yang berbeda.

\section{a. Tataran Fonologis pada Kata Serapan Bahasa Arab terhadap Bahasa Bima}

Berdasarkan buku Linguistik Bandingan Historis ada dua macam bentuk perubahan fonologis pada kata-kata serapan, yaitu: ${ }^{30}$

\footnotetext{
${ }^{29}$ Siti Maryam, Bandar Bima (Jakarta: Dekdikbud, 1992), 81.

${ }^{30}$ Gorys Keraf, Linguistik Bandingan Historis, (Jakarta: Gramedia, 1984), 80-94.
} 


\section{1) Berdasarkan Tipe- Tipe Perubahan Fonetis}

a) Penyerapan Linier; Yaitu penerapan dengan tetap mempertahankan ciri- ciri fonetis dan fonem asalnya, seperti kata: bahasa Bima kabata diserap dari bahasa Arab yaitu $\quad{ }^{31}$ yang memiliki fonem yang sama dan memiliki konteks arti yang masih sama dengan makna aslinya dari bahasa Arab yaitu mengejek atau menghina. Demikian juga kata nafsu serapan dari bahasa Arab memiliki arti dan cara penyebutan yang mempertahankan ciri- ciri fonem aslinya.

b) Penyerapan dengan perubahan atau penyesuaian; Yaitu bila fonem asalnya mengalami perubahan atau penyesuaian dengan fonem pada bahasa penyerap. Contoh; kata Bahasa Arab kabar atau diserap dalam bahasa Bima menjadi Haba karena penyesuaian.

c) Penyerapan dengan penghilangan; Yaitu kata yang diserap menghilang ketika sudah menjadi kata dari bahasa yang menyerap. Contoh; kata bahasa Arab nama akhir Bilal Bin Rabah yaitu diserap dalam bahasa Bima menjadi Robo yang berarti pengurus masjid.

d) Penyerapan dengan penambahan; Yaitu munculnya suatu fonem baru dalam bahasa yang menyerap. Contoh; kata bahasa Arab atau Fardhu diserap dalam bahasa Bima menjadi Faradu ada penambahan huruf a.

e) Penanggalan parsial; yaitu fonem yang ada pada kata yang diserap menghilang ketika masuk ke dalam bahasa yang menyerap sedangkan sebagian lain dari ciri fonem tersebut bertahan dalam bahasa yang menyerap. Contoh; kata atau nikaah diserap dalam bahasa bima menjadi nika. Atau نية atau niyah menjadi nia. Dan atau haram menjadi hara.

f) Perpaduan (merger); adalah memadukan dua fonem atau lebih pada kata yang diserap berpadu menjadi satu fonem baru. Contoh; kata atau Muwaafaqah menjadi mafaka yang bermana kesepakatan/persetujuan.

g) Pembelahan (split); merubah suatu fonem kata yang diserap membelah diri menjadi dua fonem baru atau lebih, atau satu fonem tersebut memantulkan

${ }^{31}$ Mahmud Yunus "Kamus Arab- Indonesia;قاموس عربية- إندونيسي" (Jakarta: Mahmud Yunus Wadzurriyah, 1990), 365. 
sejumlah fonem yang berlainan dalam bahasa yang menyerap. Contoh; kata kopi قهوة atau qohwah diserap menjadi kahawa.

\section{2) Berdasarkan Macam- Macam Perubahan Bunyi}

a) Asimilasi yaitu situasi ketika terdapat dua bunyi sintagmatik, atau linier hubungan keduanya sehingga bunyi satu lebih mirip dengan bunyi lainnya. ${ }^{32}$ Contoh; kata akhirat أخيرة diserap menjadi Ahera dan kata akhir أخير diserap menjadi ahi.

b) Disimilasi yaitu bunyi yang berubah menjadi kurang mirip dengan yang lain di sekitarnya. ${ }^{33}$ contoh: kata diserap menjadi Toba.

c) Perubahan berdasarkan tempat dapat diperoleh beberapa macam perubahan أقيقة) bunyi, yaitu: Metatesis ( menjadi Tasabe artinya tasbih), Aferesis menjadi Keka artinya akikah), Sinkop ( menjadi husu artinya khusus), Apokop ( menjadi ada artinya adat), Epentesis/ mesogok ( menjadi magari artinya maghrib)

\section{Tataran Semantik pada Kata Serapan Bahasa Arab terhadap Bahasa Bima}

Semantik adalah bidang studi yang mempelajari makna atau arti dalam bahasa. ${ }^{34}$ Perubahan semantik atau perubahan makna dapat ditinjau dari beberapa segi yaitu; Pertama; Generalisasi/ perluasan; (kata atau zakat fitrah dan atau zakat mal digeneralisasikan dalam bahasa Bima menjadi jeka). Kedua; Spesialisasi (kata atau abada artinya hamba Allah diserap dalam bahasa Bima menjadi musli dan muslima), Ketiga; Ameliorasi/ peninggian; (kata atau ummi dan kata atau abun diserap dalam bahasa Bima menjadi Umi dan $a b u$ yang artinya ibu dan bapak hanya bagi yang sudah haji), Keempat; Peyorasi/ penurunan; (kata atau abda/abdi yang artinya pengabdi dalam bahasa Bima mengalami peyorasi menjadi ada yang artinya Babu/ pembantu, jika konteksnya pengabdian pada manusia), Kelima; Sintesia/ pertukaran; (kata atau fikir menjadi atau fajar jika dalam bahasa Bima diungkakan menjadi "Fiki na bune taroa Faja sidi ai" artinya Pikirannya seperti Terang Fajar pagi), Keenam; Asosiasi persamaan; (kata rijal artinya laki-laki

\footnotetext{
${ }^{32}$ Abdul Syukur Ibrahim dan Machrus Syamsudin, Prinsip dan Metode Linguistik Historis, (Surabaya: Usaha Nasional, 1979), 16.

${ }^{33}$ Ibid.,

${ }^{34}$ Abdul Chaer, Pengantar Semantik Bahasa Indonesia, (Jakarta: Rineka Cipta, 1990), 2.
} 
dalam bahasa Bima berubah makna menjadi pacar laki-laki) perubahan makna yang terjadi karena persamaan sifat. ${ }^{35}$

\section{BENTUK KOSAKATA SERAPAN BAHASA ARAB DALAM BAHASA BIMA}

\begin{tabular}{|l|l|l|c|l|l|}
\hline No & \multicolumn{1}{|c|}{$\begin{array}{c}\text { BAHASA } \\
\text { BIMA }\end{array}$} & \multicolumn{1}{|c|}{$\begin{array}{c}\text { ARTI } \\
\text { ARAB }\end{array}$} & \multicolumn{1}{c|}{ TRANSLITE } \\
RASI
\end{tabular}

\footnotetext{
${ }^{35}$ Lamuddin Finoza, Komposisi bahasa Indonesia, (Jakarta: Diksi Insan Mulia, Cet. Ke , 92003), 82.
} 


\begin{tabular}{|c|c|c|c|c|c|}
\hline 41 & Arwa & Arwah & & Arwah & Arwaah \\
\hline 42 & Arsi & Arsip & أرْشثِيْف & Arsip & Arsip \\
\hline 43 & Asa & Waktu ashar & & Ashar & 'Ashar \\
\hline 44 & Asali & Asli & & Asli & Ashli \\
\hline 45 & Asura & Bulan sura & & Sura & As-Suaraa' \\
\hline 46 & Astagfirula & Astagfirullah & & Astagfirullah & Astaghfirullah \\
\hline 47 & $\mathrm{Ba}$ & Bab buku & & $\mathrm{Bab}$ & $\mathrm{Bab}$ \\
\hline 48 & Bala & Bala & & Bala & Balaa \\
\hline 49 & Bale & Balig & بليغ & Cukup umur & Baligh \\
\hline 50 & Bahi & Pelit & بخيل & Pelit & Bakhil \\
\hline 51 & Bamiya & Okra & بامية & Okra & Baamiyah \\
\hline 52 & Bati & Batil & & Batil & Bathil \\
\hline 53 & Bareka & Berkah & & Berkah & Barakah \\
\hline 54 & Bila & $\begin{array}{l}\text { Muadzin (dari } \\
\text { nama Bilal bin } \\
\text { Rabbah) }\end{array}$ & & Bilal & Bilaal \\
\hline 55 & Bid'a & Bid'ah & & Bid'ah & Bid'ah \\
\hline 56 & Bura & $\begin{array}{l}\text { Burak } \\
\text { (kendaraan } \\
\text { Nabi) }\end{array}$ & & Burak & Buraaq \\
\hline 57 & Dafta & Daftar & & Buku catatan & Daftar \\
\hline 58 & Daja & Pembohong & & Pembohong & Dajjal \\
\hline 59 & Daraja & Kedudukan & & Kedudukan & Darajah \\
\hline 60 & Darura & Susah & & Darurat & Daruurat \\
\hline 61 & Duha & Sholat duha & & Duha & Dhuhaa \\
\hline 62 & Dunia & Dunia & دنيا & Dunia & Duniaa \\
\hline 63 & Doa & Doa & & Doa & Du'aa \\
\hline 64 & Faha & Faham & فهم & Faham & Fahm \\
\hline 65 & Faja & Fajar/ pagi & & Fajar/pagi & Fajr \\
\hline 66 & Faki & Fakir & فقير & Miskin & Fakiir \\
\hline 67 & Fateha & Fatihah & فتيد & Fatihah & Fatiihah \\
\hline 68 & Faradu & Fardu/Wajib & & Fardu/ Wajib & Fard \\
\hline 69 & Fase & Fasih & فَصِينح & Lancar & Fashiih \\
\hline 70 & Fiki & Pikir & & Piker & Fikr \\
\hline 71 & Ga'i & Ghaib & & Gaib & Ghaaib \\
\hline 72 & Ghiba & Gibah & & Gibah & Ghibaah \\
\hline 73 & Ganima & Harta rampasan & & Harta rampasan & Ghaanimah \\
\hline 74 & $\mathrm{Ha}$ & Hal & & Hal & Haalah \\
\hline 75 & $\mathrm{Ha}$ & Hak & & Hak & $\mathrm{Haq}$ \\
\hline 76 & Haba & Kabar & & Kabar & Khabar \\
\hline 77 & Habe & $\begin{array}{l}\text { Panggilan } \\
\text { orang Arab }\end{array}$ & حبيب & Kekasih & Habiib \\
\hline 78 & Hadara & Hadrah & & Hadrah & Hadhrah \\
\hline 79 & Hadi & Hadir & 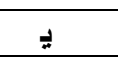 & Hadir & Haadhiir \\
\hline 80 & Hadi & Hadis & حديث & Hadits & Hadits \\
\hline 81 & Hadia & Hadiah & هادية & Hadiah & Hadiyah \\
\hline 82 & Haji & Haji & & Haji & Haaji \\
\hline 83 & Hakeka & Hakikat & حَقِيْقة & Hakikat & Haqiiqah \\
\hline 84 & Haki & Hakim & & Hakim & Hakim \\
\hline
\end{tabular}




\begin{tabular}{|c|c|c|c|c|c|}
\hline 85 & Hala & Halal & & Halal & Halaal \\
\hline 86 & Hami & Khamis & & Kamis & Khamis \\
\hline 87 & Hasa & Hasad & & Hasad & Hasad \\
\hline 88 & Hara & Haram & & Hukum haram & Haram \\
\hline 89 & Haraka & Harakot & & Tanda baca & Harakah \\
\hline 90 & Harim & Istri/pacar $\operatorname{Pr}$ & حَريْم & Istri & Hariim \\
\hline 91 & Hata/ Tama & Khatam & & Akhir & Khatam \\
\hline 92 & Hiana & Hianat & خيانة & Hianat & Khiyaanah \\
\hline 93 & Hidaya & Petunjuk & هداية & Petunjuk & Hidaayah \\
\hline 94 & Huku & Hukum & & Hukum & Hukmuh \\
\hline 95 & Hurafa & Khurafat & & Khurafat & Khurafat \\
\hline 96 & Huru & Huruf & & Huruf & Huruf \\
\hline 97 & Hutba & Hutbah & & Pidato & Khutbah \\
\hline 98 & Hita & Sunat/Hitan & & Sunat/hitan & Khitaan \\
\hline 99 & Hija & Hijab & & Hijab & Hijab \\
\hline 100 & Hoso & Khusus & & Khusus & Khusyu' \\
\hline 101 & Hotba & Khutbah & & Khutbah & Khuthbah \\
\hline 102 & Horoma & Hormat & & Hormat & Ihtiroom \\
\hline 103 & Husu & Khusus & & Khusus & Khaashah \\
\hline 104 & Ibada & Ibadah & & Ibadah & Ibadah \\
\hline 105 & Ibli & Iblis & إبِْْيْس & Iblis & Ibliis \\
\hline 106 & Ihla & Ihlas & & Ihlas & Ikhlash \\
\hline 107 & Ihtia & Ihtiar & إِخْتِيَارُ & Usaha & Ikhtiar \\
\hline 108 & Ikra & Buku Iqro & & Baca & Iqraa \\
\hline 109 & Itika & I tikaf & & I'tikaf & Itikaaf \\
\hline 110 & Ija & Ijab & & Jawab & Ijaab \\
\hline 111 & Ijasa & Ijazah & & Surat izin & Ijaazah \\
\hline 112 & Iji & Izin & & Izin & Izin \\
\hline 113 & Ijra`i & Izrail & عِزرائيل & Izrail & Izrail \\
\hline 114 & Israfi & Israfil & اسر افيل & Israfil & Israfil \\
\hline 115 & Ilmu & Ilmu & & Ilmu & Ilm \\
\hline 116 & Isla & Islam & & Islam & Islam \\
\hline 117 & Istihara & Istiharah & & Istiharah & Istiharah \\
\hline 118 & Istila & Istilah & & Istilah & Ishtilaah \\
\hline 119 & Istigfa & Istigfar & & Istigfar & Istagfara \\
\hline 120 & Inji & Injil & إنجيْيْل & Injil & Injil \\
\hline 121 & Ima & Iman & إيمان & Iman & Iimaan \\
\hline 122 & Ima & Imam & & Pemimpin & Imaam \\
\hline 123 & Infa & Infak & & Infak & Infaq \\
\hline 124 & Insa & Insaf & & Insaf & Insaaf \\
\hline 125 & Insa & Manusia & & Manusia & Insaan \\
\hline 126 & Inka & Ingkar & & Ingkar & Inkar \\
\hline 127 & Isa & Sholat isya & & Isya & Isya \\
\hline 128 & Isla & Islam & & Islam & Islam \\
\hline 129 & Jama & Zaman & & Zaman & Zaman \\
\hline 130 & $\mathrm{Ji}$ & Jin & & Jin & Jin \\
\hline 131 & Janaba & Junub & & Junub & Janaabah \\
\hline 132 & Janaja & Jenazah & & Jenazah & Janaazah \\
\hline
\end{tabular}




\begin{tabular}{|c|c|c|c|c|c|}
\hline 133 & Jama & Zaman & & Zaman & Zamaan \\
\hline 134 & Jasa & Jasad & & Jasad/badan & Jasad \\
\hline 135 & Jawa & Jawab & & Jawab & Jawaab \\
\hline 136 & Jabara`i & malaikat jibril & جبريل & malaikat jibril & Jibriil \\
\hline 137 & Jadwa & Jadwal & & Jadwal & Jadwal \\
\hline 138 & Jama & Sholat jama` & & Jumat & Jumu'ah \\
\hline 139 & Jeka & Zakat & & Zakat & Zakah \\
\hline 140 & Jendera & Jendral & & Jendral & Jiniraal \\
\hline 141 & Jiki & Zikir & & Mengingat & Dzakara \\
\hline 142 & Jilba & Jilbab & & Jilbab & Jilbab \\
\hline 143 & Jiha & Jihad/berjuang & جهَاد & Jihad/berjuang & Jihaad \\
\hline 144 & Jiki & Zikir & & Zikir & Zikir \\
\hline 145 & Jina & Zina & & Zina & Zina \\
\hline 146 & $\mathrm{Ju}$ & Juz al-quran & & Bagian & Juz' \\
\hline 147 & Jumla & Jumlah & & Kalimat & Jumlah \\
\hline 148 & Juma`a & Hari Jum`at & & Hari Jum'at & Jumu`ah \\
\hline 149 & Julhija & Julhijah & & bulan julhijah & Dzulhijjah \\
\hline 150 & Julqaida & Julqaidah & & Julqaidah & Djulqoidah \\
\hline 151 & Joli & Zolim & & Zolim & Dzoolim \\
\hline 152 & Ka`ba & Ka`bah & & Ka'bah & Ka'bah \\
\hline 153 & Kaba & Sombong & & Besar & Akbar \\
\hline 154 & Kabata & Menghina & & Menghina & Kabata \\
\hline 155 & Kabu & Kabul & & Diterima & Qabuul \\
\hline 156 & Kafara & Kafarat & & Kafarat & Kafaarat \\
\hline 157 & Kafi & Kafir & & Kafir & Kafir \\
\hline 158 & Kahawa & Kopi & قهوة & Kopi & Qohwah \\
\hline 159 & Kalima & Kalimat & & Kalimat & Kalimah \\
\hline 160 & Karo`a & Qur`an & & Qur'an & Qur'aan \\
\hline 161 & Kama & Iqomah sholat & & Mendirikan & Iqaamah \\
\hline 162 & Kamus & Kamus & & Kamus & Qaamuus \\
\hline 163 & Karama & Karomah & & Kemuliaan & Karaamah \\
\hline 164 & Kiama & Kiamat & قِيَامَة & Kiamat & Qiyaamah \\
\hline 165 & Kibla & Kiblat & & Kiblat & Kiblat \\
\hline 166 & Kita & Kitab & & Kitab & Kitaab \\
\hline 167 & Kurba & Kurban & & Kurban & Qurbaan \\
\hline 168 & Kurma & kurma & & Pohon kurma & Karm \\
\hline 169 & Keka & Akikah & عقيقة & Akikah & Aqiqah \\
\hline 170 & Lafa & Lafaz, ucapan & & Lafaz & Lafaz \\
\hline 171 & Laha & lahat/kubur & & lahat/kubur & Lahad \\
\hline 172 & Laji & Lazim & & Lazim/wajar & Laazim \\
\hline 173 & Lakna & Laknat & & Laknat & Laknat \\
\hline 174 & Lilla & Lillah & له & Lillah & Lillah \\
\hline 175 & Lisa & Lisan & & Lidah & Lisan \\
\hline 176 & Loho & Zuhur & ظهز & Zuhur & Dzuhur \\
\hline 177 & Ma'ana & Arti & & Arti & Ma'na \\
\hline 178 & Mafaka & Mufakat & & Kesepakatan & Muwafiq \\
\hline 179 & Magari & Magrib & & Timur & Maghrib \\
\hline 180 & Maha & Mahar & مهر & Mahar & Mahar \\
\hline 181 & Makaru & Makruh & & Hukum makruh & Makruh \\
\hline
\end{tabular}




\begin{tabular}{|c|c|c|c|c|c|}
\hline 182 & Malaeka & Malaikat & & Malaikat & Malaaikah \\
\hline 183 & Majali & Majlis & & Majlis & Majlis \\
\hline 184 & Majala & Majalah & & Majalah & Majallah \\
\hline 185 & Maka & Kota mekkah & & Makkah & Makkah \\
\hline 186 & Makena & Mukenah & & Mukenah & Muknah \\
\hline 187 & Maksia & Maksiat & مَعْصِيَة & Maksiat & Ma'siah \\
\hline 188 & Maksu & Maksud & & Maksud & Maksud \\
\hline 189 & Maya & Mayat & ميْت & Mayat & Mayyit \\
\hline 190 & Mimba & Mimbar & & Mimbar & Minbar \\
\hline 191 & Mika`i & Mikail & مِيْكَائيْلِ & Mikail & Miikaaiil \\
\hline 192 & Miski & Miskin & مِسنكِيْنَ & Miskin & Miskiin \\
\hline 193 & Muba & Mubah & & Mubah & Mubah \\
\hline 194 & Muhamma & $\begin{array}{l}\text { Muhammad } \\
\text { Nabi }\end{array}$ & & $\begin{array}{l}\text { Nabi } \\
\text { Muhammad }\end{array}$ & Muhammad \\
\hline 195 & Muhara & Muharram & & Muharram & Muharram \\
\hline 196 & Muhli & Muhlis & & Muhlis & Muhklish \\
\hline 197 & Mukmi & Mukmin & مؤمين & Mukmin & Mu'miin \\
\hline 198 & Mungka & Mungkar & & Mungkar & Munkar \\
\hline 199 & Musawara & Musawarah & & musawarah & Musyawarah \\
\hline 200 & Musha & Mushaf & & Mushaf & Mushaf \\
\hline 201 & Musli & Muslim & & Muslim & Muslim \\
\hline 202 & Musri & Musrik & & Musrik & Musyrik \\
\hline 203 & Musi & Musik & مُوسبيقِي & Musik & Muusiik \\
\hline 204 & Musiba & Musibah & مُصِيْبَة & Musibah & Mushibah \\
\hline 205 & $\mathrm{Na}^{\prime} \mathrm{ji}$ & Najis & & Na'jis & Najis \\
\hline 206 & Nabi & Nabi & & Nabi & Nabi \\
\hline 207 & Nafa & Nafas & & Nafas & Nasf \\
\hline 208 & Nafasu & Nafsu & & Nafsu & Nafsu \\
\hline 209 & Nafka & Nafkah & & Nafkah & Nafaqah \\
\hline 210 & Naja & Nazar & & Nazar & Nadzar \\
\hline 211 & Nanki & Malaikat Nakir & نكير & Nakir & Nakir \\
\hline 212 & $\mathrm{Nia}$ & Niat & نِيَّة & Niat & Niah \\
\hline 213 & Nika & Nikah & & Nikah & Nikah \\
\hline 214 & Nikma & Nikmat & & Nikmat & Nikmah \\
\hline 215 & $\mathrm{Nu}$ & Cahaya & & Cahaya & Nuur \\
\hline 216 & Nuzulu & Nuzulul & & Nuzulul & Nuzulul \\
\hline 217 & Raja & Bulan rajab & & Bulan rajab & Rajab \\
\hline 218 & Raka'a & Rakaat sholat & & Rakaat sholat & Raka'aat \\
\hline 219 & Ramada & $\begin{array}{l}\text { Bulan } \\
\text { ramadhan }\end{array}$ & & $\begin{array}{l}\text { Bulan } \\
\text { Ramadhan }\end{array}$ & Ramadhon \\
\hline 220 & Rahma & Rahmat & & Rahmat & Rahmah \\
\hline 221 & Rahi & Penyayang/ & رجسيْمِ & Penyayang & Rahiim \\
\hline 222 & Rasu & Nabi/Utusan & & Utusan & Rasul \\
\hline 223 & Rido & Ridho & & Ridho & Ridho \\
\hline 224 & Riwaya & Riwayat & رواية & Riwayat & Riwayah \\
\hline 225 & Rijal & Pacar laki & & Laki- laki & Rijaal \\
\hline 226 & Robo & $\begin{array}{l}\text { Pengurus } \\
\text { Masjid }\end{array}$ & & Bilal bin rabah & Rabah \\
\hline
\end{tabular}




\begin{tabular}{|c|c|c|c|c|c|}
\hline & & $\begin{array}{l}\text { (Rabah;akhir } \\
\text { nama Bilal) }\end{array}$ & & & \\
\hline 227 & Ruku & Rukun sholat & & Rukun sholat & Rukun \\
\hline 228 & $\mathrm{Sa}$ & Shaf sholat & & Shaf & Shof \\
\hline 229 & $\mathrm{Sa}$ & Sah & & Sah & Shah \\
\hline 230 & Sadeka & Sedekah & & Sedekah & Sodaqoh \\
\hline 231 & Saha & Sah/Absah & & Benar & Sohih \\
\hline 232 & Sahada & Sahadat & شهادة & Sahadat & Syahadah \\
\hline 233 & Sajada & Sajadah & & Sajadah & Sajadah \\
\hline 234 & Sajara & Sejarah & & Pohon & Syajarah \\
\hline 235 & Salawa & Salawat & & Salawat & Sholawaat \\
\hline 236 & Sale & Saleh & & Saleh & Sholih \\
\hline 237 & Safa & Bulan Safar & & Safar/ nol & Safar \\
\hline 238 & Sa`ba & Bulan Sa`ban & & Bulan sa'ban & Sya'baan \\
\hline 239 & Safa`a & Safaat & & $\begin{array}{l}\text { Safaat/pertolon } \\
\text { gan }\end{array}$ & Syafaa'at \\
\hline 240 & Sara & Syarat & & Syarat & Syarat \\
\hline 241 & Sare'a & Syariat & شُرَّريْعَة & Hukum islam & Syarii'ah \\
\hline 242 & Seta & Setan & شيطان & Setan & Syaitoon \\
\hline 243 & Siri & Syirik & & Sirik & Sirik \\
\hline 244 & Soba & Sahabat & & Kawan & Shaabah \\
\hline 245 & Suna & Sunah & & Sunah & Sunnah \\
\hline 246 & Sura & Surat & & Surat & Suurah \\
\hline 247 & Subu & Subuh & & Subuh & Subh \\
\hline 248 & Suju & Sujud & & Sujuud & Sujuud \\
\hline 249 & Suku & Sukun-tajwid & & Bacaan Mati & Sukun \\
\hline 250 & Sulta & Sultan & & Raja & Sulton \\
\hline 251 & Saleha & Salehah & & Salehah & Shaalehah \\
\hline 252 & Sahada & Sahadat & شه & Sahadat & Syahaadah \\
\hline 253 & Salasa & Selasa & & Selasa & Tsulaatsaa \\
\hline 254 & Sarowa & Celana & & Celana & Sirwaal \\
\hline 255 & Sifa & Sifat & & Sifat & Sifah \\
\hline 256 & Sihi & Sihir & & Sihir & Sihir \\
\hline 257 & Takli & Taklim & 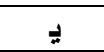 & Belajar & Ta'liim \\
\hline 258 & Tahaju & Tahajud & تهجد & Tahajud & Tahjud \\
\hline 259 & Tafaku & Merpikir & & Berpikir & Tafakur \\
\hline 260 & Tadaru & Tadarus & & Mempelajari & Tadarus \\
\hline 261 & Tama & Khatam quran & & Tutup & Khatam \\
\hline 262 & Takabi & Takbir & تكبير & Takbir & Takbiir \\
\hline 263 & Takdi & Takdir & تقدير & Takdir & Takdiir \\
\hline 264 & Takabu & Takabur & & Takabur & Takabbur \\
\hline 265 & Takli & Taklid & تقليا & Taklid & Taqlid \\
\hline 266 & Takwa & Taqwa & & Takwa/ takut & Taqwaa \\
\hline 267 & Takti & Taktik & تَكَتِتِكْ & Taktik & Taktiik \\
\hline 268 & Tahayu & Tahayul & تَحَيُّل & Khayalan & Takhayyul \\
\hline 269 & Tarawe & Sholat Tarweh & تراويح & Taraweh & Taraawiih \\
\hline 270 & Tarti & Tartil qur'an & ترتيل & Tartil & Tartiil \\
\hline 271 & Tareka & Tarekat & 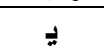 & Jalan/cara & Tariikah \\
\hline 272 & Telefo & Telepoh & & Telepon & Tilfoon \\
\hline
\end{tabular}




\begin{tabular}{|l|l|l|l|l|l|}
\hline 273 & Toa & Taat & & Taat & Too`at \\
\hline 274 & Toba & Tobat & & Kembali & Taubah \\
\hline 275 & Toko & Menduduki & & Menguasai & Tooqo \\
\hline 276 & Uju & Juz Alquan & & Bagian & Juz \\
\hline 277 & Ulama & Ulama & & Berilmu & 'Ulamaa \\
\hline 278 & Uma & Umat & & Umat & Ummah \\
\hline 279 & Umi & Ibu Haji & & Ibu & Ummi \\
\hline 280 & Umu & Umur & & Umur & Umur \\
\hline 281 & Waktu & Waktu & & Waktu & Waqt \\
\hline 282 & Waji & Wajib & & Wajib & Waajib \\
\hline 283 & Waka & Wakaf & & Wakaf & Wakaf \\
\hline 284 & Wasia & Wasiat & Wasiat & Wasia \\
\hline 285 & Waktu & Waktu & & Waktu & Waqt \\
\hline 286 & Wajir & Petugas & Petugas & Waajiir \\
\hline
\end{tabular}

\section{E. KESIMPULAN}

Kajian tentang analisis serapan kosakata bahasa Arab terhadap Bahasa Bima merupakan kajian sosiolinguistik yang mengkaji hubugan antara bahasa dengan masyarakat yang saling mempengaruhi antara satu sama lain. Adapun proses terjadinya penyerapan kosakata bahasa Arab terhadap bahasa Bima yaitu; Proses ekspansi Islam ke Bima yang di bawa oleh para ulama Bugis, Ternate, Arab dan Melayu sangat kuat. Penyebaran Islam di Bima mengenalkan masyarakat Bima pada istilah-istilah kata Arab sehingga dalam kehidupan sehari-hari juga menggunakan istilah Arab tersebut. Proses berikutnya yaitu imbas dari masuknya Islam di Bima yaitu perubahan sistem pemerintahan kerajaan Bima menjadi kesultanan Bima, yang mana dalam sendi-sendi kehidupannya menjadikan Islam sebagai landasan hidup. Sehingga yang awalnya menggunakan bahasa aksara bima diubah menjadi inskripsi Bima yang ditulis dalam bahasa Arab dan bahasa Melayu, bukan dengan huruf dan bahasa Bima atau Bugis. Sistem kerajaan dirubah menjadi sistem kerajaan Islam/kesultanan yang mana naskah, aturan hukum merujuk pada penulisan Arab dan hukum Islam. Proses selanjutnya melalui perdagangan, posisi geografis Bima menjadi salah satu pusat perdagangan pada rute lintas Malaka dan Maluku yang merupakan daerah yang disinggahi sepanjang rute pelayaran-perdagangan. Bima sebagai salah satu bandar lintas pelayaran- perdagangan Malaka dan Maluku menjadi penting. Sehingga menarik para pedagang Arab dan Melayu untuk datang ke Bima, diantara hubungan perdagangan tersebut terjadi kontak budaya yang menyebabkan adanya penyerapan bahasa 
Arab dalam bahasa Bima, apalagi orang Arab pada masa itu juga turut andil dalam penyebaran ilmu-ilmu Islam.

Bentuk kosakata bahasa Bima hasil serapan dari bahasa Arab beragam, baik dari tatanan fonologi maupun semantiknya. Berdasarkan Tipe-Tipe Perubahan Fonetik terdiri dari: Penyerapan Linier (kabata- $\quad$ ), Penyerapan dengan perubahan atau penyesuaian (haba ), Penyerapan dengan penghilangan (sene - إسنين), Penyerapan dengan penambahan (faradu - $\quad$ ), Penanggalan parsial (hara - ）, Perpaduan/merger (mafaka - _ ), dan Pembelahan/ split (jeka - ) ). Berdasaran Macam- Macam Perubahan Fonetik yaitu Asimilasi , Disimilasi dan Perubahan berdasarkan tempat dapat diperoleh beberapa macam perubahan bunyi, yaitu: Metatesis, Aferesis, sinkope, apokop, protesis, Epentesis/ mesogok dan, paragok.

Semantik adalah bidang studi yang mempelajari makna atau arti dalam bahasa ${ }^{36}$. Perubahan semantik atau perubahan makna dapat ditinjau dari beberapa segi yaitu; Pertama; Generalisasi/ perluasan; (kata atau zakat fitrah dan atau zakat mal digeneralisasikan dalam bahasa Bima menjadi jeka). Kedua; Spesialisasi (kata atau abada artinya hamba Allah diserap dalam bahasa Bima menjadi musli dan muslima), Ketiga; Ameliorasi/ peninggian; (kata atau ummi dan kata atau abun diserap dalam bahasa Bima menjadi Umi dan $a b u$ yang artinya ibu dan bapak hanya bagi yang sudah haji), Keempat; Peyorasi/ penurunan; (kata atau abda/abdi yang artinya pengabdi dalam bahasa Bima mengalami peyorasi menjadi ada yang artinya Babu/ pembantu, jika konteksnya pengabdian pada manusia), Kelima; Sintesia/ pertukaran; (kata atau fikir menjadi atau fajar jika dalam bahasa Bima diungkakan menjadi "Fiki na bune taroa Faja sidi ai" artinya Pikirannya seperti Terang Fajar pagi), Keenam; Asosiasi persamaan; (kata rijal artinya laki-laki dalam bahasa Bima berubah makna menjadi pacar laki-laki) perubahan makna yang terjadi karena persamaan sifat.

\footnotetext{
${ }^{36}$ Abdul Chaer, Pengantar Semantik Bahasa Indonesia, (Jakarta: Rineka Cipta, 1990), 2.
} 


\section{DAFTAR PUSTAKA}

Abdu Chaer dan Leonie Agustina, Sosiolinguistik: Perkenalan Awal, Jakarta: PT Rineka Cipta, 1995.

Abdul Chaer, Pengantar Semantik Bahasa Indonesia, Jakarta: Rineka Cipta, 1990.

Abdul Ibrahim Syukur, dan Machrus Syamsudin, Prinsip dan Metode Linguistik Historis, Surabaya: Usaha Nasional, 1979.

Azyumardi Azra, Jaringan Ulama Timur Tengah Dan Kepulauan Nusantara Abad Xvii Dan Xviii: Melacak Akar- Akar Pembaruan Pemikiran Islam di Indonesia, Bandung; Mizan, Cet. 3, 1995.

Emzir, Metodologi Penelitian Kualitatif Analisis Data, Jakarta: PT RajaGrafindo Persada, 2010.

Erwin, dkk. Penggunaan Bahasa Mbojo Di Lingkungan Masyarakat Bima Di Bima: Sebuah Kajian Variasi Bahasa. e-Journal Program Pascasarjana Pendidikan Ganesha Program Studi Pendidikan Bahasa dan Sastra Indonesia Volume 2, 2013.

Fachrir Rahman, Nika Mbojo Antara Islam Dan Tradisi, Mataram: Alamtara Institut, 2011.

Gorys Keraf, Linguistik Bandingan Historis, Jakarta: Gramedia, 1984.

Henri Chambert Loir, dan Siti Maryam R. Salahuddin, Bo' Sangaji Kai: Catatan Kerajaan Bima, Yogyakarta: Yayasan Obor Indonesia, 2013.

Husaini Usman, dkk, Metodologi Penelitian Sosial, Jakarta: PT. Bumi Aksara, 2006.

I Wayan Tama, dkk, Fonologi Bahasa Bima, Jakarta: Depdikbud, 1996.

Lamuddin Finoza, Komposisi bahasa Indonesia, Jakarta: Diksi Insan Mulia, Cet. Ke 9. 2003.

M.Hilir Ismail, Kebangkitan Islam di Dana Mbojo (BIMA) Bogor: CV Binasti, 2008.

Mardalis, Metode Penelitian: Suatu Pendekatan Proposal, Jakarta: Bumi Aksara, 2008.

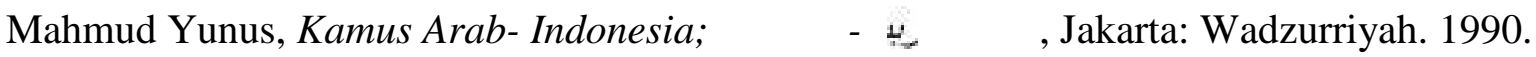

Samsuri, Analisa Bahasa, Jakarta: Erlangga, Cet. Ke 9. 1994.

Siti Maryam, Bandar Bima. Jakarta, Depdikbud, 1992.

Suwito, Pengantar Awal Sosiolinguistik Teori dan Problema, Surakarta: UNS Press, 1983.

Tawalinuddin Haris, dkk, Kerajaan Tradisional di Indonesia- Bima, Jakarta: CV. Putra Sejati Raya, 1997. 